\title{
Assessment of the Association of Some Socio-demographic Characteristics with Mother-child Relationship in Mothers Who Have Children in Primary Schools \\ Neslihan Aslan ${ }^{1}$ and Ayșe Ferda Ocakçaki ${ }^{*}$
}

${ }^{1}$ Yüksek Lisan Öğrencisi, Koç Üniversitesi, Turkey

${ }^{2}$ School of Nursing, Koç Üniversitesi, Turkey

Abstract

Objective: The present investigation was planned as a descriptive study to investigate the association of some socio-demographic characteristics with mother-child relationship in mothers who have children in primary schools.

Materials and Methods: The universe of the study consisted of mothers of children aged 6-12 years attending to randomly selected 2 primary and secondary schools located in Istanbul province. Mothers of all children existed in the study universe were included into the study and mothers of a total of 214 children accepting to participate into the study have constituted the study sample. Data collection was performed using Child and Mother Information Form and Parental Accoptance - Rejection Questionnaire - Mother Form. Data were collected by face to face interviews with mothers.

Results: Results demonstrated that mother's age, educational level, number of children and monthly income have a significant negative association with rejecting behavior.

Conclusion: Gender of the child and family type have no significant association with mother-child relationship.

\section{Background}

School age period means 6-12 years children. During school age period physical growth slows down, cognitive development speeds up and friends gain more importance than the family [1]. Positive or negative relation between the child and his mother influence the relations that the child establish with others and his peers. In addition; mother-child relation has an impact on adaptation to the school [2].

In mother-child relation, positive relation comes through compassion, concern, fondness feelings that mother fells for her child. Sincere and receptive relation between the mother, father and the child allow the child develop his autonomy and self-esteem. The children who are not able to establish positive relation with their mothers might possibly perform aggressive and dependent behaviours and they also have lower self-confidence levels. Such traumas at childhood period lead to acquiring of harmful habits such as drug, alcohol addiction [3].

The importance of mother-child relation is mentioned in various theories. Freud emphasises the effect of a healthy mother-child relation on child's future personality in his physcosexual development stages [4]. Similarly, Erikson states that the quality of mother-child interaction, caring,safety and autonomy feelings which the child gets from his mother, are vital concepts for the child to develop as healthy individuals [5]. Mother-child relation is absolutely crucial for 6-12 years children's physcosocial, cognitive and physcosexual development. A peadiatric nurse should be aware of such problems stemming from mother-child relation and should strive to resolve such problems.

A peadiatric nurse should search for helath mother-child relation as well as the factors that might affect the relation negatively. She should provide support to the mother or the family whenever they need in order to establish a positive relation with their child [6]. Searching for the effects of certain sociodemographic characteristics such as Child's age, gender, number of siblings, age of parents, education status, occupation status etc on mother-child relation might contribute the preparation and implementation of mother-child education programmes within the scope of results of such searches mentioned above. Recognising of effects of socio demographic characteristics on mother-child relation is rather important in the planning of nursing interventions. Thus; the study aims to assess some Socio-demographic Characteristics with Mother-child Relationship in Mothers Who Have Children at Primary Schools.

\section{Universe and Sample}

The universe of the study included mothers of 6-12 years primary and elemantary school children in Istanbul between the dates of October, 2015 and February, 2016. As fort he selection of schools, ramdomly selecting sampling technique was preferred and 2 primary and elementary school was selected accordingly in Istanbul. Between the dates stated above, mothers of 6-12 years children who have not diagnosed any health problems and mothers who are volunteer to participate in the study and also accept signing the information and approval forms both written and verbally were included in the sample group. Sample of the study consisted of 214 mothers meeting the needs of selection criteria and agreeing to participate in the study voluntarily.

\section{Data Collection Tools}

In the study data collection was performed using Child-Family Information Form and Parental acceptance-Rejection Questionnaire (a.k.a Mother Form) data collection tools were explained in detail below:

"Corresponding Author: Prof. Ayşe Ferda Ocakçaki, School of Nursing, Koç Üniversitesi, Turkey; E-mail: aocakci@ku.edu.tr

Citation: Aslan N, Ocakçak AF (2016) Assessment of the Association of Some Socio-demographic Characteristics with Mother-child Relationship in Mothers Who Have Children in Primary Schools. Int J Nurs Clin Pract 3: 215. doi: https:// doi.org/10.15344/2394-4978/2016/215

Copyright: @ 2016 Aslan et al. This is an open-access article distributed under the terms of the Creative Commons Attribution License, which permits unrestricted use, distribution, and reproduction in any medium, provided the original author and source are credited. 


\section{Child-Family Information Form}

It is a questionnaire prepared by the researcher as a result of detailed scanning of the Literature in order to clarify demographic characteristics of the mothers included in the study and their families as well. For mothers, Child-Family Information Form consists of 12 items; child's age, gender, Parent's age, educational status and occupation.

\section{Parental Acceptance - Rejection Questionnaire - Mother Form}

The questionnaire, developed by Rohner, Savedro and Granum, was translated into Turkish by Polat and Sunar in 1986 and reviewed finally in 1993 by Anjel and Erkman. Its validity and reliability were tested on 229 mothers in Turkey. Total Alpha-coefficient was determined as 0.90 . Re-test of the quesitonnaire was performed after two and three weeks respectively and its Pearson correlation Coefficient value was found as 0.46 . due to the similarity between Mother's Form and ChildAdult forms validity of the questionnaire was accepted as appropriate. The Parental Acceptance - Rejection Questionnaire (Mother Form) mesures mothers' acceptance and rejection of their children from mothers' perspectives. The Parental Acceptance - Rejection Questionnaire (Mother Form) is a Likert-type questionnaire cosisting of four sub-dimensions and 56 items; Fondness and Love (20 items), Agression and Hostility (16 items), Indifference and Neglect (12 items) and Disaggregated Rejection (8 items).

Fondness and Love dimension of the tool assesses both parental acceptance including such emotions as fondness, affection and love and/or parental rejection including verbal or physical contemplations such as (I always tell good things about my child.). Agression and Hostility dimension measures the emotions felt by the parents for the child such as anger, hatred and malevolance ( I scold and humiliate my child when he performs inappropriate behaviors. ) Indifference and Neglect dimension of the tool evaluates parents' being indifferent and neglectful to their children. ( I behave as if my child is not there). Disaggregated Rejection dimension measures the attributes of mothers towards their cihldren that might possible cause child's feeling himself worthless even if rejective behaviors do not exist appereantly. ( 1 do not know exactly whether I love my child or not).

Parental Acceptance - Rejection Questionnaire (Mother Form) is a four-options tool, scoring from 4 to 1 meaning: "always true", "somtimes true", "rarely true" and "never true". Items numbered 1, 5, $7,8,12,14,15,18,20,24,26,27,31,33,34,38,40,41,45,47,48,51$, 53,54 and 56 are encoded reversely. Top score of the tool is 240 and the lowest score is 60 . Scores of sub-dimensions and higher scores mean high level of rejection that is lower level of acceptance of the mothers to their children. Higher scores from sub-dimensions and in total scores suggests an unhealthy mother-child relationship. The tool includes the perception of mothers' acceptance and rejection to their children and it can only be applied to mothers having $3+$ years children [7].

\section{Data Collection}

Before collecting the required data for the study, mothers were nformed by the researcher via face-to-face interviews. Following the informing process, volunteer mothers were signed written approval forms. During the data collection process, researchers were colloborated with the school management and interviews with mothers were planned seperately for each grades. In these interviews mothers were enlighted about the process and content of the study by the researcher and they were asked to sign written approval forms to participate in the study. They were also applied data collection forms by the researcher. To the mothers who were not able to participate in the interviews, school principal sent the data collection forms and provided them information about the study. Volunteer mothers were invited to the school and they were asked to fill in the questionnaire by face-to-face interviews with the researcher. Each of the interviews lasted approximately 15-20 minutes.

\section{Assessment of the Data}

In the assessment of the data SPSS Statistics for Windows 22 Programme was used. As fort he bio-statistical analysis of the study, the measures taken into consideration were identified through mean, standart deviation, frequency and percentage values. Parental Acceptance - Rejection Questionnaire (Mother Form) was evaluated follwing the calculation of sub-dimensions' scores seperately. For each of the dimensions, total score was calculated in the first hand, after that the mean score was calculated by taking the total scores of sub-dimensions into consideration. In order to identify the relation between two digital variables Pearson Correlation Analysis, to find out the difference between two groups "t-test" and to realize single direction variant analysis for independent groups Kruskal Wallis Test were benefited. Test statistics were evaluated according to $\mathrm{p}<0.05$ significancy level [8].

\section{Finding}

\begin{tabular}{|c|c|c|}
\hline & Number & $\%$ \\
\hline \multicolumn{3}{|l|}{ Educational Status } \\
\hline Primary & 47 & 22 \\
\hline Elementary & 54 & 25.2 \\
\hline High-school & 75 & 35 \\
\hline University & 38 & 17.8 \\
\hline \multicolumn{3}{|l|}{ Monthly Income } \\
\hline Minimum Wage & 19 & 8.9 \\
\hline $1000-1500 \mathrm{TL}$ & 34 & 15.9 \\
\hline $1500-2000 \mathrm{TL}$ & 32 & 15.0 \\
\hline $2000-2500 \mathrm{TL}$ & 65 & 30.4 \\
\hline $2500-3000 \mathrm{TL}$ & 36 & 16.8 \\
\hline $3000 \mathrm{TL}$ or more & 28 & 13.1 \\
\hline \multicolumn{3}{|c|}{ Number of Children } \\
\hline 1 & 35 & 16.4 \\
\hline 2 & 103 & 48.1 \\
\hline 3 & 57 & 26.6 \\
\hline $4+$ & 19 & 8.9 \\
\hline \multicolumn{3}{|l|}{ Type of Family } \\
\hline Extended & 40 & 18.7 \\
\hline Nuclear & 174 & 81.3 \\
\hline \multicolumn{3}{|l|}{ Social Security } \\
\hline Yes & 205 & 95.8 \\
\hline No & 9 & 4.2 \\
\hline
\end{tabular}

Table 1: Sociodemographic Characteristics $(\mathrm{N}=214)$. 
Of the 214 participant mothers; $(n=5) 2.3 \%$ of them are between the ages of $18-25,(n=80) 37.4 \%$ of them are between the ages of $26-33$, $(n=96) 44.9 \%$ of them are between the ages of $34-41$ and $(n=33) 15.4 \%$ of them are above the age of 42 . Of the mothers; $(n=38) 17.8 \%$ of them are university, $(n=75) \% 35$ of them are high school, $(n=54) 25.2 \%$ of them are elemantary school and $(\mathrm{n}=47) 22 \%$ of them are primary school graduates.

The mean ages of children are $9.19 \pm 1.91(\min =6, \max =12)$ and $(n=111) 51.9 \%$ of them are males, $(n=103) 48.1 \%$ of them are females. Of the mothers; $(n=35) 16.4 \%$ of them have only child, $(n=103) 48.1 \%$ of them have two children, $(n=57) 26.6 \%$ of them have three children and $(n=19) 8.9 \%$ of them have four or more children. Of the families; $(n=206) 95.8 \%$ of them have social-security, $(n=9) 4.2 \%$ of them do not have any social securities.

Of the families; $(n=40) \quad 18.7 \%$ of them are extended family and $(n=174) 81.3 \%$ of them are nuclear family. As for the monthly income of the families; $(n=19) 8.9 \%$ minimum wage, $(=34) 15.9 \%$ of them between 1000-1500 Turkish Liras, $(n=32) 15 \%$ of them between 1500 $2000 \mathrm{TL},(\mathrm{n}=65) 30.4 \%$ of them between $2000-2500 \mathrm{TL},(\mathrm{n}=36) 16.8 \%$ of them between $2500-3000 \mathrm{TL}$ and $(\mathrm{n}=28) 13.1 \%$ of them earns 3000 TL or more (Table 1).

Lowest of the mean acceptance-rejection scores obtained from Parental Acceptance - Rejection Questionnaire (Mother Form) are detected in "disagregated rejection" sub-dimension (19.91) and the highest score was found in "warmth-affection" sub-dimension (48.78) (Table 2).

\begin{tabular}{|l|l|l|l|}
\hline & Mean score & $\begin{array}{l}\text { Minimum } \\
\text { score }\end{array}$ & $\begin{array}{l}\text { Maximum } \\
\text { score }\end{array}$ \\
\hline Warmth-Affection & 48.78 & 40 & 56 \\
\hline Agression-Hostility & 35.92 & 27 & 46 \\
\hline Indifference-Neglect & 23.38 & 16 & 41 \\
\hline $\begin{array}{l}\text { Disaggregated } \\
\text { Rejection }\end{array}$ & 19.91 & 13 & 26 \\
\hline Total score & 128.01 & 110 & 157 \\
\hline
\end{tabular}

Table 2: Mean Scores of Total and sub-dimensions of Parental Acceptance - Rejection Questionnaire (Mother Form) (N=214).

Sub-dimensions mean scores of Parental Acceptance - Rejection Questionnaire (Mother Form) and total mean scores do not indicate a statistically significant difference regarding the age of cihldren. However, the mean scores of "Indifference and Neglect" subdimension have a negatively statistically significant association with the age of children. (Table 3.) $(\mathrm{r}=-0.146, \mathrm{p}=0.032 \mathrm{p}<0.05)$.

A negative statistically significant relation was detected between "Neglect" sub-dimension of the Parental Acceptance - Rejection
Questionnaire (Mother Form) and mother's age. $(\mathrm{r}=-0.20, \mathrm{p}=0.003$, $\mathrm{p}<0.05) \quad($ Table 2). A negative statistically significant relation was also detected between total score of Parental Acceptance Rejection Questionnaire (Mother Form) and age of mothers. ( $\mathrm{r}=$ $-0.15, p=0.02, p<0.05) \quad$ Not any statistically significant relation was observed between "Hostility\&Agreesion, Warmth\&Affection and Disaggregated Rejection" subdimensions of Parental Acceptance Rejection Questionnaire (Mother Form) ( $>$ > 0.05) (Table 3).

A positive-statistically significant relation was detected between "Indifference-Neglect" subdimentsion of the Parental Acceptance Rejection Questionnaire (Mother Form) and number of children in the family. $(r=0.169, p=0.01, p<0.05)$ (Table 2$)$ In addition, a positivestatistically significant relation was found out between the "total score" of Parental Acceptance - Rejection Questionnaire (Mother Form) and number of children $(\mathrm{r}=0.182, \mathrm{p}=0.007, \mathrm{p}<0.05)$ (Table 2) in the family. Not any statistically significant relations were observed between mean scores of "Hostility\&Agreesion, Warmth\&Affection and Disaggregated Rejection" subdimensions of Parental Acceptance - Rejection Questionnaire (Mother Form) and number of children in the family ( $p>0.05)$ (Table 3$)$.

Not any statistically significant relations were found out between mean scores of Parental Acceptance - Rejection Questionnaire (Mother Form) sub-dimensions and total score of participant mothers obtained from Parental Acceptance - Rejection Questionnaire (Mother Form) and monthly income of the family. ( $p>0.05)$ (Table 3).

Not any statistically significant difference were detected between mean scores of participant mothers and and gender of the children. (p>0.05) (Tablo 4).

\begin{tabular}{|l|l|l|l|}
\hline EKRÖ & \multicolumn{2}{|c|}{ Gender } & $\mathrm{P}$ \\
\hline & $\begin{array}{l}\text { Girl } \\
\mathrm{X} \pm \mathrm{SD}\end{array}$ & $\begin{array}{l}\text { Boy } \\
\mathrm{X} \pm \mathrm{SD}\end{array}$ & \\
\hline Warmth-Affection & $49.06 \pm 2.79$ & $48.52 \pm 3.04$ & 0.17 \\
\hline Agression-Hostility & $35.78 \pm 3.26$ & $36.06 \pm 3.59$ & 0.55 \\
\hline Indifference-Neglect & $23.33 \pm 4.94$ & $23.42 \pm 3.94$ & 0.89 \\
\hline Disaggregated Rejection & $19.89 \pm 1.79$ & $19.93 \pm 1.30$ & 0.84 \\
\hline Total score & $128.03 \pm 8.55$ & $127.94 \pm 8.06$ & 0.90 \\
\hline
\end{tabular}

Table 4:Total and sub-dimensions Mean Scores Regarding the Gender of Child ( $\mathrm{N}=214)$.

A statistically significant difference was identified between "warmth\&affection" sub-dimension and educational status of the mothers. (KW= 8.25, p=0.001, $\mathrm{p}<0.05) \quad$ When the educational status of the mothers are paid attention in "warmth\&affection" subdimension, it is obvious that elemantary school graduate mothers

\begin{tabular}{|l|l|l|l|l|l|l|l|l|l|l|l|l|}
\hline & \multicolumn{2}{|l|}{ Warmth-Affection } & \multicolumn{2}{l|}{ Agression-Hostility } & \multicolumn{2}{l|}{ Indifference-Neglect } & \multicolumn{2}{l|}{ Disaggregated Rejection } & \multicolumn{2}{l|}{ Total score } \\
\hline & $\mathrm{r}$ & $\mathrm{p}$ & $\mathrm{r}$ & $\mathrm{p}$ & $\mathrm{r}$ & $\mathrm{p}$ & $\mathrm{r}$ & $\mathrm{p}$ & $\mathrm{r}$ & $\mathrm{p}$ \\
\hline Age of the child & 0.11 & 0.08 & -0.86 & 0.21 & -0.14 & 0.03 & 0.005 & 0.93 & -0.71 & 0.29 \\
\hline Age of the mother & -0.09 & 0.16 & -0.07 & 0.25 & -0.20 & 0.003 & 0.1 & 0.14 & -0.15 & 0.02 \\
\hline Number of childrn & 0.12 & 0.05 & 0.08 & 0.23 & 0.16 & 0.01 & 0.06 & 0.34 & 0.18 & 0.007 \\
\hline Income & -0.19 & 0.77 & -0.31 & 0.65 & -0.11 & 0.86 & -0.04 & 0.48 & -0.03 & 0.61 \\
\hline
\end{tabular}

Table 3:The Relation Between Age of Child, Age of Mother, Number of Children, Monthly Income of The Family and Mean Scores of Parental

Acceptance - Rejection Questionnaire (Mother Form) (N=214). 
have the highest scores. (49.50 \pm 2.68$)$ (Table 5) A statistically significant difference was pointed between "Indifference\&Neglect" sub-dimension of the Parental Acceptance - Rejection Questionnaire (Mother Form) and educational status of mothers. (KW=13.62, $\mathrm{p}=0.003, \mathrm{p}<0.05)$ Furthermore; mean scores of elemantary school graduate mothers are the highest for "Indifference\&Neglect" subdimension. (24.75 \pm 4.01$)$ (Table 5). It has been found out that there is a statistically significant difference between "total score" of mothers obtained from Parental Acceptance - Rejection Questionnaire (Mother Form) and their educational status. (KW=9.02, $\mathrm{p}=0.02$, $\mathrm{p}<0.05)$ The elemantary school graduate mothers have the highest score in this dimension. (130.59 \pm 7.56$)$ (Table 5) Additionally, "agression\&hostility" and "disaggregated rejection" sub-dimensions of Parental Acceptance - Rejection Questionnaire (Mother Form) do not include any statistically significant difference regarding educational status of mothers (Table 5).

A statistically significant difference was identified between "warmth\&affection" sub-dimension and educational status of the mothers. $(\mathrm{KW}=8.25, \mathrm{p}=0.001, \mathrm{p}<0.05)$ When the educational status of the mothers are paid attention in "warmth\&affection" sub-dimension, it is obvious that elemantary school graduate mothers have the highest

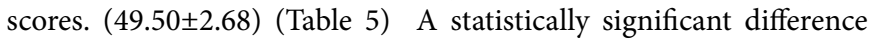
was pointed between "Indifference\&Neglect" sub-dimension of the Parental Acceptance - Rejection Questionnaire (Mother Form) and educational status of mothers. $(\mathrm{KW}=13.62, \mathrm{p}=0.003, \mathrm{p}<0.05)$ Furthermore; mean scores of elemantary school graduate mothers are the highest for "Indifference\&Neglect" sub-dimension. $(24.75 \pm 4.01)$ (Table 5). It has been found out that there is a statistically significant difference between "total score" of mothers obtained from Parental Acceptance - Rejection Questionnaire (Mother Form) and their educational status. $(\mathrm{KW}=9.02, \mathrm{p}=0.02, \mathrm{p}<0.05)$ The elemantary school graduate mothers have the highest score in this dimension. (130.59 \pm 7.56$)$ (Table 5) Additionally, "agression\&hostility" and "disaggregated rejection" sub-dimensions of Parental Acceptance - Rejection Questionnaire (Mother Form) do not include any statistically significant difference regarding educational status of mothers (Table 5).

\section{Discussion}

At the present study acceptance-rejection mean scores of the mothers they obtained from Parental Acceptance - Rejection Questionnaire (Mother Form) arehigher than the mean scores of Önder and Gülay's [9] study in which they look into the relation between mothers' acceptance -rejection levels to their children as well as the emphaty skills of 4-5 and 6th grades students. Higher scores refer higher level of rejection by the mother. According to results of the present study, mothers have rejectionist attributes to their primary school cihldren (Table 2).
The number of studies utilizing Parental Acceptance - Rejection Questionnaire (Mother Form) are fairly limited. In the Literature, the studies, using Parental Acceptance - Rejection Questionnaire (Mother Form) in order to assess child's acceptance-rejection from mother's perspective, are usually conducted for pre-school children. In Ural et al's [10] study ,analysing the relation between acceptancerejection behaviors of mothers having pre-school children and social behavior control, it has been found out that mothers have high level of acceptance towards their pre-school age children. Similarly, Tepeli et al. [11] examined 5-6 yeared children's understanding of their own emotions in terms of mother's acceptance-rejection and suggested that mothers' acceptance is higher to their pre-school age children . Furthermore; Erkman and Rohner's [12] study, which deals with perceived mother acceptance of young individuals, suggests that mothers have higher level of acceptance towards their pre-school age children.

According to findings of the present study, mothers perform more indifferent and neglectful behaviors towards their children as they get older (table 3). Ozana et al's study, analyzing the relation between acceptance-rejection levels of pre-school children's mothers and social behavior control, indicated that total score of Parental Acceptance - Rejection Questionnaire (Mother Form) and scores of its sub-dimensions differentiate according to age of the children [10]. In Erkman and Rohner's study [12] that investigates the possible cahnge of parental acception or rejection in terms of age of the children, it was deduced that mothers' acceptance-rejection behaviors did not differentiate according to ages of children. The study carried out by Veneziano [13] namely "Perceived Paternal and Maternal Acceptance and Psychological Adaptation of Rural Afro-American and European-American Youngsters" emphasised that there were not any relations between mothers' acceptance-rejection of their children and age of the children.

At the present study, it has been indicated that mean scores of the sub-dimensions and total scores of the Parental Acceptance - Rejection Questionnaire (Mother Form) do not indicate statistically significant difference in terms of gender of children (table 4). Thus; acceptance behaviors of mothers do not differentiate according to gender of the children. So, it might be stated that mothers have the same level of acceptance-rejection towards their boys and girls. Similarly; Ogelman and Çubuk [6] emphasised in their study, investigating the relation between maternal acceptance-rejection behaviors and gender of 114 pre-school children by appling Parental Form, that maternal acceptance levels do not differentiate in terms of gender of the children. In addition, Erkan and Toran [14] analized acceptancerejection behaviors of 123 mothers having 5 years children applying Personal Information Form and Parental Acceptance - Rejection

\begin{tabular}{|c|c|c|c|c|c|}
\hline \multirow[t]{2}{*}{ EKRÖ } & \multicolumn{2}{|c|}{ Educational Status } & & & \multirow[t]{2}{*}{$\mathrm{P}$} \\
\hline & $\begin{array}{l}\text { Primary } \\
\mathrm{X} \pm \mathrm{SD}\end{array}$ & $\begin{array}{l}\text { Elementary } \\
\mathrm{X} \pm \mathrm{SD}\end{array}$ & $\begin{array}{l}\text { HighSchool } \\
\mathrm{X} \pm \mathrm{SD}\end{array}$ & $\begin{array}{l}\text { University } \\
\mathrm{X} \pm \mathrm{SD}\end{array}$ & \\
\hline Warmth-Affection & $48.44 \pm 3.46$ & $49.50 \pm 2.68$ & $48.25 \pm 2.95$ & $49.23 \pm 2.2$ & 0.04 \\
\hline Agression-Hostility & $35.85 \pm 3.70$ & $36.42 \pm 3.41$ & $35.84 \pm 3.30$ & $35.50 \pm 3.45$ & 0.69 \\
\hline Indifference-Neglect & $22.46 \pm 4.75$ & $24.75 \pm 4.01$ & $23.70 \pm 4.66$ & $21.92 \pm 3.55$ & 0.003 \\
\hline Disaggregated Rejection & $20.10 \pm 2.14$ & $19.90 \pm 1.17$ & $19.72 \pm 1.52$ & $20.07 \pm 1.26$ & 0.66 \\
\hline Total score & $126.87 \pm 9.39$ & $130.59 \pm 7.56$ & $127.52 \pm 8.38$ & $126.73 \pm 7.20$ & 0.029 \\
\hline
\end{tabular}

Table 5: The Relation Between Educational Status of Mother and Total-subdimension scores of Mother Form (N=214). 
Questionnaire (Mother Form) and they put forth that maternal acceptance-rejection behaviors do not show any difference according to gender. Many of the studies, searching the relation between parental acceptance-rejection levels and gender of the children supports the idea that gender of the children has not any influence on parental acceptance-rejection behaviors $[15,16,17,12,6,18,10,8]$. On the other hand, different views on that issue are available in the Literature. Ummunel [19] reported in his study that sub-dimension scores of mothers from "Warmth and Love", "Agression and Hostility", "Indifference and Neglect" do not differentiate significantly in terms of gender of the children. Nevertheless, "Disagregated Rejection" levels do indicate certain difference according to gender of the children . Haktanır et al. [20] remarked in their study that expectations of families might differ according to gender of the children and parental behaviors and attributes towards the children are shaped accordingly.

According to findings of the present study, as mothers aging thier "Inddeference and Neglect" levels towards their 6-12 years children decreases or vice versa. Total score of Parental Acceptance - Rejection Questionnaire (Mother Form) indicates maternal acceptancerejection to their children. So that it might be deduced that as mothers grow older they perform more acceptable behaviors and establish healtier relations with their children (Table 3). Erkan and Toran [14] found out a positively significant but statistically weak relation between age of mothers and total scores obtained from Parental Acceptance - Rejection Questionnaire (Mother Form). So, mothers from lower socioeconomic group get older lead to increase in the level of rejection towards their children. In the overall review of Haktanır et al. [20](16) of 75 studies about mother-child relation, it was stated that age of mothers did not have a significant influence on on behaviors towards their children. However, Campo and Rohner [21] reported in their study that as mothers getting older their behaviors towards their children change significantly in negative way.

Participant mothers' "Indifference-Neglect" sub-dimension scores indicate statistically significant difference from their educational status (Table 5). When the mean scores of mothers are observed, it is clear that primary school graduate mothers have the highest scores. That means primary school graduate mothers neglect their 6-12 years children more compared to others. Erkan and Toran assert in their study that as mothers' educational level decreases, their rejection behaviors increase and vice versa [14] (13). In many other studies, it has been put forth that increase in mothers' educational levels rises the percentage of their acceptive behaviors and decrease in their educational levels increase their rejective-negative behaviors towards their children $[22,23,20,3,24]$. A statistically positive significant relation is detected between participant mothers' 'IndifferenceNeglect" sub-dimension scores and number of children in the family. Thus; increasing number of children means more "Indifferent and Neglectful" behaviors for participant mothers (table 3). In their study Erkan and Toran [14] ascertained that there is a statistically positive relation between total score of Parental Acceptance - Rejection Questionnaire (Mother Form) and number of children mothers have. So that; it is possible to mention that increase in the number of children for mothers of lower socioeconomic status is the reason for increase in rejective behaviors they perform towards the children. Studies on this issue clarify that in families with many children mothers have negative influence on children' social development; thay behave as punishers and they become more indifferent and neglectful towards their children by transferring motheirng role to their elder child. They also insufficient to meet their children's pyschological and physchological needs [23].
Participant mothers' sub-dimension and total scores are not directly related with their monthly income. There is not statistically significant relation between mothers' scores obtained from Parental Acceptance Rejection Questionnaire (Mother Form) and monthly income of the family (Table 3). According to results of the present study, monthly income of the family does not affect mother's acceptance-rejection behaviors. Raver's [25] study on mothers from lower socioecenomic status reveals opposite findings from ours. Raver [25] asserts in his study that lower income level of the family cause a drop in mother's care and affect the physchological adaptation of the mother negatively as well. Additionally, in the study carried out by Demiriz and Öğretir [26], analyzing mother attributes of 10 years children 300 in total -143 girls, 157 boys- it has been reported that mothers from lower socioecenomic status are more protective, more rejective to their mothering roles, more quarrelsome in the family and more disciplined towards their children. Similar findings exist in various studies conducted in our country. Altan [22] stated that lower socioeconomic groups mothers' children perceive more maternal rejectionand less maternal warmth. Çakıcı compared acceptance and rejection behaviors of mothers from both lower and higher socioecenomic status and deduced that mothers of lower socioecenomic group have more rejective behaviors [17]. In other studies conducted in our country, it was reported that increase in the number of family members leads to a decrease in mother's care of her child, hinders her mothering role, and reasons for performing indifferent and neglectful behaviors to her child.

\section{Conclusion}

The present study has demonstrated that sociodemographic characteristics of mothers such as age, educational status, number of children and monthly income have significant effect on their acceptance-rejection behaviors. However, gender of the children and type of the family have no significant effect on acceptance-rejection behaviors.

According to results of the present study the following issues might be recommended;

- Pediatric nurses should conduct researches with larger sample groups in order to determine problematic issues for motherchild relations.

- Pediatric nurses should plan family-centered educational programmes. The nurse should explain clearly to the family their children are social and physchosocial beings and the family should also be informed on characteristics of their children's development stages, emotional needs and the importance allocating time for them.

- In order to support developmental characteristics of the child at school, the concept of "school nurse" should be placed and ensured to function appropriately. School nurse should deliver related services by taking the child's developmental characteristics into consideration. School nurse should plan growth and development monitoring for children at regular intervals. Children should be provided family-centered care at schools. School nurse should monitor child's interaction with his family, especially his mother and the nurse should provide consultancy about mother-child relation when needed.

\section{Competing Interests}

The authors declare that they have no competing interests. 


\section{References}

1. Ansari ZA (2002) Parental acceptance-rejection of disabled children in nonurban Pakistan. North American Journal of Psychology 4: 121-128.

2. Berry D, O'connor E (2010) Behavioral Risk, Teacher-Child Relationships, and Social Skill Development Across Middle Childhood:A Child-ByEnvironment Analysis of Change. Journal of Applied Developmental Psychology 31: 1-14.

3. Sümer N, Güngör D (1999) Çocuk Yetiştirme Stillerinin Bağlanma Stilleri, Benlik Değerlendirmeleri Ve Yakın İlişkiler Üzerindeki Etkisi. Türk Psikoloj Dergisi 14: 35-58.

4. Geçtan E (2008) Psikanaliz ve Sonrası. 13. Baskı. İstanbul: Metis Yayıncılık.

5. Gander MJ, Gardiner HW (2001) Çocuk ve Ergen Gelişimi, (Yay. Haz. B.Onur), 4. Baskı, Ankara: Imge Kitapevi.

6. Ogelman H, Çabuk F (2013) 5 Yaş Çocuklarının Sosyal Konumlarının Anne Babalarının Kabul Red Düzeyleri İle İlişkisinin İncelenmesi. Süleyman Demirel Üniversitesi Sosyal Bilimler Enstitüsü Dergisi 2: 18.

7. Öner N (1996) Türkiye'de Kullanılan Psikolojik Testler, Bir Başvuru Kaynağı, İstanbul: Boğaziçi Üniversitesi Yayınları.

8. Yener N (2005). Çocukların Algıladıkları Ebeveyn Kabul veya Reddinin Okul Başarısı ve Okul Uyumu İle İlişkisi. Yayınlanmamış Yüksek Lisans Tezi, Ege Üniversitesi Sosyal Bilimler Enstitüsü.

9. Önder A, Gülay H (2007) Annelerin Kabul Ret Düzeyi İle Çocuklarının Empati Becerisi Arasındaki İlişkinin İncelenmesi. Pamukkale Üniversitesi Eğitim Fakültesi 22: 23-30.

10. Ural O, Güven G, Efe-Azkeskin K, Sezer T, Yılmaz E, et al. (2015) Oku Öncesi Dönemde Çocuğu Olan Annelerin Kabul-Red Düzeyleri İle Sosya Davranış Denetimleri Arasındaki İlişkinin İncelenmesi. Akademik Sosyal Araştırmalar Dergisi 3: 456-471.

11. Tepeli K, Yılmaz E, Kuyucu Y (2014) Studying Emotion Recognition Skills Of 5-6 Year Old Children In Terms Of Maternal Acceptance/Rejection Levels, Contemporary Perscpectives and Research on Early Childhood Education, (Eds. Mustafa Yaşar, Özkan Özgün and Jeanne Galbraith), Newcastle, UK: Cambrideg Scholar Publishing.

12. Erkman F, Rohner RP (2006) Youths' Perceptions of Corporal Punishment Parental Acceptance and Psychological Adjustment in a Turkish Metropolis. Cross Culterel Research 40: 250-267.

13. Veneziano RA (2000) Perceived Paternal And Maternal Acceptance And Rural African American And European American Youths' Psychological Adjustment. Journal of Marriage and the Family 62: 123-132.

14. Erkan S, Toran M (2004) Alt Sosyo-Ekonomik Düzey Annelerinin Çocuklarını Kabul ve Reddetme Davranışlarının İncelenmesi (Diyarbakır İli Örneği). Hacettepe Üniversitesi Eğitim Fakültesi Dergisi 27: 91-97.

15. Arıkan D, Çelebioğlu A, Tüfekçi FG (2013) Çocukluk Dönemlerinde Büyüme ve Gelişme. Conk, Z., Başbakkal, Z., Yılmaz, H.B., Bolışık, B. (der.). Pediatri Hemşireliği. Ankara: Akademisyen Tıp Kitapevi :75-79.

16. Anjel M, Erkman F (1993) The Transliteral Equivalence, Reliability and Validity Studies of the Parental Acceptance-Rejection Questionnaire (PARQ) Mother-Form: A tool for Assessing Child Abuse. International Society for Prevention of Child Abuse \& Neglect-Regional Conference, Boğaziçi University, Istanbul.

17. Çakıcı S (2006) Alt ve Üst Sosyoekonomik Düzeydeki Ailelerin Anne-Çocuk İlişkilerinin ve Aile İşlevlerinin Anne-Çocuk İlişkilerine Etkisinin İncelenmesi”. Yüksek Lisans Tezi, Gazi Üniversitesi, Eğitim Bilimleri Enstitüsü, Ankara.

18. Toran M (2005) Farklı sosyo kültürel düzeylere sahip annelerin çocuklarını kabullenme ve reddetme davranışlarının incelenmesi. Yüksek Lisans Tezi. Hacettepe Üniversitesi, Sosyal Bilimler Enstitüsü, Ankara.

19. Ummunel A (2007) Okul Öncesi Çocuklarda Akran Kabulünün Çeşitli Değişkenler Açısından İncelenmesi. Yayınlanmamış Yüksek Lisans Tezi, Ankara Üniversitesi Eğitim Bilimleri Ensittüsü, Türkiye.

20. Haktanır G, Aral N, Alisinanoğlu F, Baran G, Başar F, et al. (1999) Türkiye'de Anne Baba Tutumu Araştırmalarına Genel Bakıs.. Cumhuriyet ve Çocuk. (Edt. B.Onur). 2. Ulusal Çocuk Kültürü Kongresi. A.Ü. Çocuk Kültürü Araştırma ve Uygulama Merkezi Yayınları, Ankara.

21. Cambo AT, Rohner RP (1992) Relationship Between Perceived Parental Acceptance-Rejection, Psychological Adjustmentand Substance Abuse Among Young Children." Child Abuse ve Neglect 16: 429-440.
22. Altan O (2006) Relations Between Maternal Socialization, Child Temperament and Emotion Regulation in Preschoolers. Unpublished Master's Thesis, Koc University, Istanbul.

23. Bilir Ş, Dabanlı D (1991) Ergenlik Çağındakinin Sosyal Gelişimine Aile Tutumlarının Etkisinin Araştırıması". Aile Yazıları III: Birey, Kişilik ve Toplum (Derleyenler: B. İpekçigil, A. Çiğdem), Ankara: Aile Araştırma Kurumu Bakanlığı Yayınları.

24. Kağıtçıbaşı Ç (1979) Çocuğun Değeri: Türkiye'de Değerler ve Doğurganlık, İstanbul: Boğaziçi Üniversitesi Yayınları.

25. Raver C (2003) The Role of Employment In Predicting Deppressive Symptoms and Parenting Among Low-Income Famillies. Child Development, 74: 6 .

26. Demiriz S, Öğretir AD (2007) Alt ve Üst Sosyo-ekonomik Düzeydeki 10 Yaş Çocuklarının Anne Tutumlarının İncelenmesi”. Kastamonu Eğitim Dergisi 15: 105-122.

27. Akgün Kostak M (2013) Hemşirelik Ve Ebelik Öğrencilerinin Çocuk Sevme Durumları, Çocuk Sağlığı Ve Hastalıkları Hemşireliği Dersinin Çocuk Sevme Durumlarına Etkisi Ve Etkileyen Faktörler". Cumhuriyet Hemşirelik Dergisi 2: 50-56.

28. Erdoğan S, Nahçivan N, Esin MN (2014) Hemşirelikte Araştırma”. İstanbul: Nobel Tıp Kitapevi, s:237-279.

29. İnanç Yazgan B, Bilgin M, Kılıç Atıcı M (2012) Gelişim Psikolojisi-Çocuk ve Ergen Gelişimi. İstanbul: Pegem A Yayıncılık s: 245-260. 